\title{
Slovakia's Foreign Trade with the Countries of the Integration Core of the Eurasian Economic Union
}

DOI 10.18267/pr.2021.krn.4816.8

\author{
Elena Kašt'áková1 - Anabela Luptáková ${ }^{2}$ \\ ORCID iD: 0000-0003-4215-48361, 0000-0003-1577-68912 \\ elena.kastakova@euba.sk, anabela.luptakova@euba.sk \\ 1,2 University of Economics in Bratislava, Faculty of Commerce, Department of \\ International Trade \\ Bratislava, Slovakia
}

\begin{abstract}
In the territorial composition of Slovakia's foreign trade, the European Union countries hold a dominant position. Slovakia has the highest negative trade balance with third countries. This fact has already been considered by the Slovak Strategy for External Economic Relations 2014-2020, which set out a pro-export orientation towards non-European territories. Russia, Belarus and Kazakhstan - the countries of integration core of the Eurasian Economic Union appertain to the priority interest of Slovakia. We examine the development of their foreign trade relations in terms of trade intensity index and intra-industry index. From the exporter's point of view, Slovakia achieved the highest trade intensity with Russia. Trade intensity with Belarus fluctuated at the same level in recent years and with Kazakhstan, there was a gradual decline. Intra-industry trade was recorded between Slovakia and selected countries within SITC $6+8$, SITC $2+4$ and SITC 5 .
\end{abstract}

Keywords: Foreign trade, trade intensity index, intra-industry index, Slovakia, Russian federation, Kazakhstan, Belarus.

JEL Classification codes: F14, F15, F19

\section{INTRODUCTION}

The Eurasian Economic Union (EAEU) plays an eminent role in Slovak foreign trade relations. The EAEU was established in 2015 and includes the Russian Federation, Belarus, Kazakhstan, Kyrgyzstan and Armenia. These countries represent a considerable sales market for Slovak products. That is one of the disputes why it is remarkably important to develop mutual trade relations with these countries. While Slovakia, with its strategic location also embodies an attractive partner for the EAEU countries. The diversification of the territorial structure of the Slovak Republic's foreign trade into EAEU markets will help to fulfill the trade policy goals of the pro-export strategy.

Foreign trade relations of the Slovak Republic are set out in the government document Strategy of External Economic Relations of the Slovak Republic for the period 2014 - 2020 (FER strategy), which is currently being updated for the period 2020 - 2030. The FER strategy aims to ensure a stable position of the Slovak Republic in international economic relations supporting the economic and social development of the country, the growth of the living standard of the population and the promotion of economic interests abroad. The FER strategy defined territorial priorities, which focused on supporting exports mainly to non-European markets and specified countries of priority interest. From the countries of the Eurasian Economic Union, the first group included the Russian Federation, Belarus and Kazakhstan. Armenia was in the second group. The division of countries set on the expected importance based on a multi- 
factor analysis, which included an evaluation of the specific interests of Slovak exporters, the selection of regions in terms of global economic development and current state intentions.

\section{LITERATURE REVIEW}

One indicator for determining the potential of mutual foreign trade is the trade intensity index. The intensity of trade depends on many factors, such as the size of economies, their level of development, the structure of GDP, their geographical location and the distance associated with transport costs or other cultural and institutional spheres. It also depends on the signed mutual trade agreements or trade barriers between the studied countries. The development tendencies of trade intensity create space for the valuation of bilateral relations from both sides on the supply and demand. This indicator was initially designed by Brown (1949) and later by Kojima (1964). They defined trade intensity as bilateral trade between two countries concerning total world trade and its share in it. Calderón \& Chong \& Stein (2007) analyzed effects of trade intensity on business cycle correlation. According to their findings, a significant difference in the impact of trade intensity on business cycle synchronization between industrial and developing-country pairs is explained by differences in the structures of production and the degree of intra-industry trade. They suggested that approximately $40 \%$ of these differences can be attributed to asymmetries in structures of production.

In foreign trade, there is an exchange of goods between and also within individual sectors. Based on this aspect, the level of their foreign trade interaction is divided between intraindustry and inter-industry trade. Inter-industry trade is an exchange of goods between different sectors. Intra-industry trade refers to an exchange of goods within the same sector. The beginnings of the study of intra-industry trade lead to the authors Grubel and Lloyd, who in 1971 brought a new perspective on the quantitative assessment of foreign trade flows within individual product groups between countries. Hamilton \& Kniest (1991), Brülhart (1994) Thom \& McDowell (1999), Crespo \& Fontoura (2004) and others later devoted themselves to the development of the idea of intra-industry trade. Several authors investigated the consequences of intra-industry trade for the political economy of trade (Lipson 1982; Milner 1997; Manger 2012; Kim 2017). Results of Baccini\&Dür\&Elsig (2018)reveal that the effect of intra-industry trade on tariff reduction is highly heterogeneous across countries.

\section{METHODOLOGY}

The paper aims to examine the development of Slovakia's foreign trade relations with the countries of the integration core of the Eurasian Economic Union in terms of the trade intensity index and the intra-industry index.

The trade intensity index (TII) is one of the methods used to assess whether trade volumes between two countries are larger or smaller than would be expected based on their position in the world economy. It is defined as the share of one country's exports to a partner country, divided by the share of world exports to the partner country (World Bank, 2010). The formula is defined as follows:

$$
\mathrm{TII}_{\mathrm{ij}}=\frac{\frac{X i j}{X i t}}{\frac{X w j}{X w t}}
$$

where the individual variables have the following interpretation:

$x_{i j}$ - value of exports from country $i$ to country $\dot{j}_{i}$

$X_{i t}$ - the value of the country's $i$ total exports to the world; 
$x_{w j}$ - the value of total world exports to country $\dot{j}_{r}$

$\mathrm{X}_{w t}-$ value of total world exports.

The index ranges from zero to infinity. If the value of the index is 1 , it means that the country $i$ exports to country $j$ the exact ratio of exports that country $j$ belongs to, in terms of its share of world imports. If the value of the index is higher than 1, trade flows between the studied countries are at a higher level than would be expected given the importance of the economy in the world economy. It means that country $i$ exports more to country $j$ than the rest of the world, which indicates an intensive business relationship. If the value is less than 1 , the trading intensity is at a lower level than would be expected. (World Bank, 2013)

Based on the development of this index we could assess changes in the trade intensity during the reporting period. We examine the intensity of trade between EAEU countries and the Slovak Republic.

For the calculation of intra-industry trade, we used the original specification of the GrubelLloyd's index, which can be expressed as:

$$
G L_{i}=\frac{\left(X_{i}+M_{i}\right)-\left|X_{i}-M_{i}\right|}{X_{i}+M_{i}}=1-\frac{\left|X_{i}-M_{i}\right|}{X_{i}+M_{i}} \quad ; 0 \leq G L_{i} \leq 1
$$

Where $X i$ expresses the export of goods in the commodity group and Mithe import of goods in the commodity group. The index acquires values ranging from 0 to 1 . If the value of the index is equal to 1 , this indicates the existence of intra-industry trade. If the value of the index is equal to 0 , then there is no intra-industry trade between the countries. This indicates the presence of inter-industry trade. From the above, it can be concluded the following causal link. The higher the value of the index, the higher the level of specialization of trade-in intra-industry exchange. Conversely, a lower index value suggests that foreign trade is closer to interindustry trade (Greenaway \& Egger, 2005).

The limitation of the research was set from 2001 to 2019 and the statistics were drawn from the International Trade Center (ITC) and Eurostat.

\section{RESULTS AND DISCUSSION}

A partial update of the FER Strategy set the priorities of the Pro-Export Policy of the Slovak Republic for the period 2018 - 2020 and under the influence of geopolitical changes adjusted the territorial priorities. Priority areas for Slovak export orientation include the countries of the Western Balkans (especially Serbia and Northern Macedonia). Then there are the countries of the Commonwealth of Independent States (mainly Russia, Belarus, Ukraine, Kazakhstan and other Central Asian countries), followed by Southeast Asia (China, Vietnam, Indonesia) and last but not least the countries such as India, USA, Canada, Brazil and Cuba. Given that the EAEU countries are among the important territorial strategies of the Slovak Republic, a detailed overview of the development of the trade involved is in the following figure 1. 
Fig. 1 Development of foreign trade between the Slovak Republic and the EAEU in the years 2001 - 2019, mil. EUR

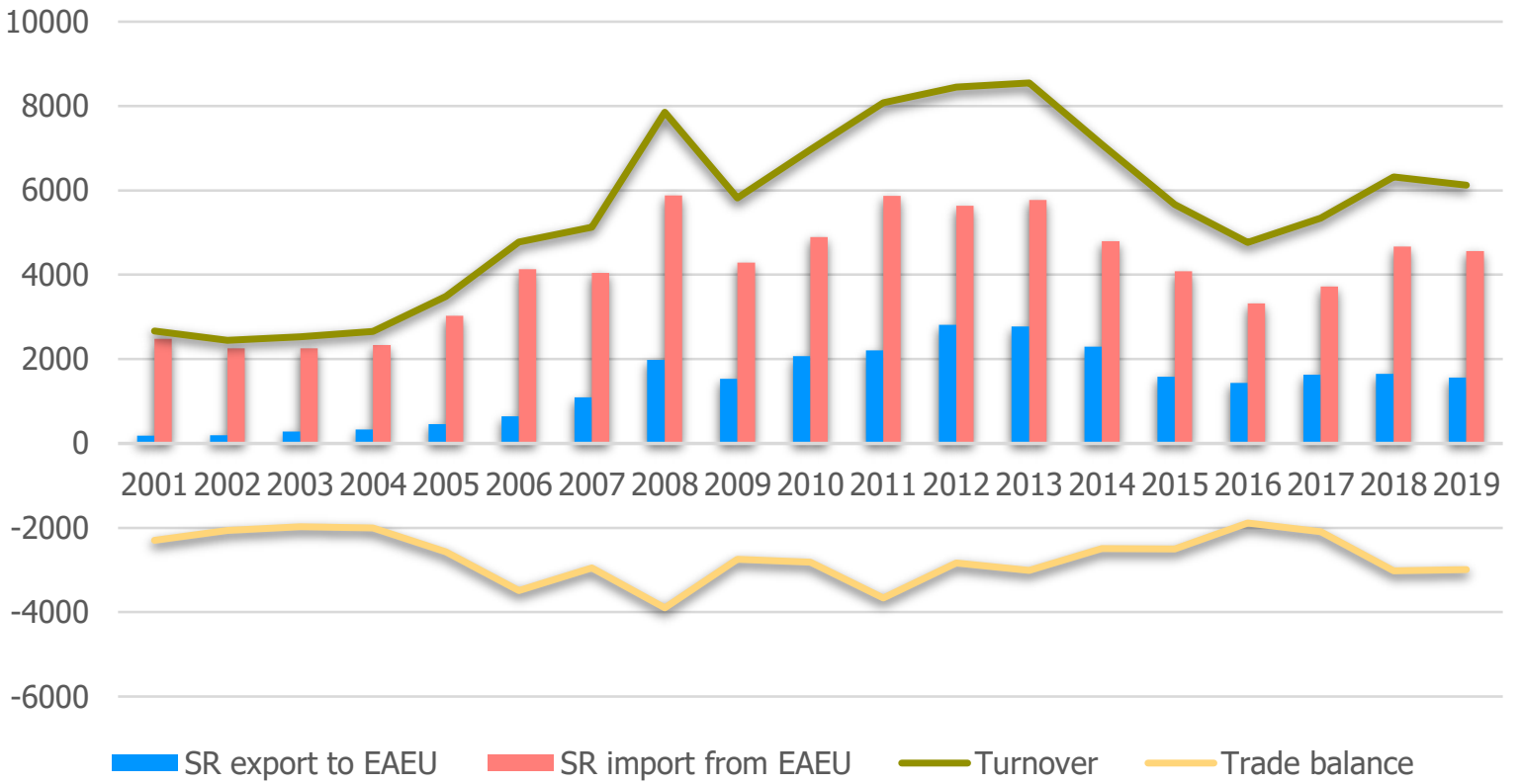

Source: author's own processing based on ITC data, 2021

Figure 1 shows the development of foreign trade between the Slovak Republic and the Eurasian Economic Union for 2001 - 2019. Until 2008, the growth trend of foreign trade prevailed, with a significant recess after 2008. Subsequently, their mutual trade showed permanent growth until 2013. After 2014, we can observe a continuous decline with a revival after 2016. During the period 2011 to 2014, the highest values of Slovak exports were observed. In 2019, the trade turnover of the Slovak Republic with the EAEU was at the level of 6127.934 mil. EUR. Slovakia had a negative foreign trade balance throughout the period under review.

\subsection{Trade intensity index of the EAEU countries with the Slovak Republic}

To evaluate the development of bilateral trade relations between the EAEU countries and Slovakia, concerning their involvement in international trade, the trade intensity index was used. In figure 2 is the development of the trade intensity from the point of view of the Slovak Republic as an importer from the EAEU. Among the EAEU countries, the Russian Federation had the highest trade intensity with the Slovak Republic during almost the entire period under review. In 2009-2010, Russia was overtaken by Kazakhstan. The Russian Federation reached values in the range of $1.75-9.16$ (from the lowest to the highest) as an exporter. As higher values than 1 were achieved, the Russian export volumes are higher than expected. Nevertheless, the index has a continuing declining trend. 
Fig. 2 Development of the trade intensity index by the EAEU countries to Slovakia in the years $2001-2019$

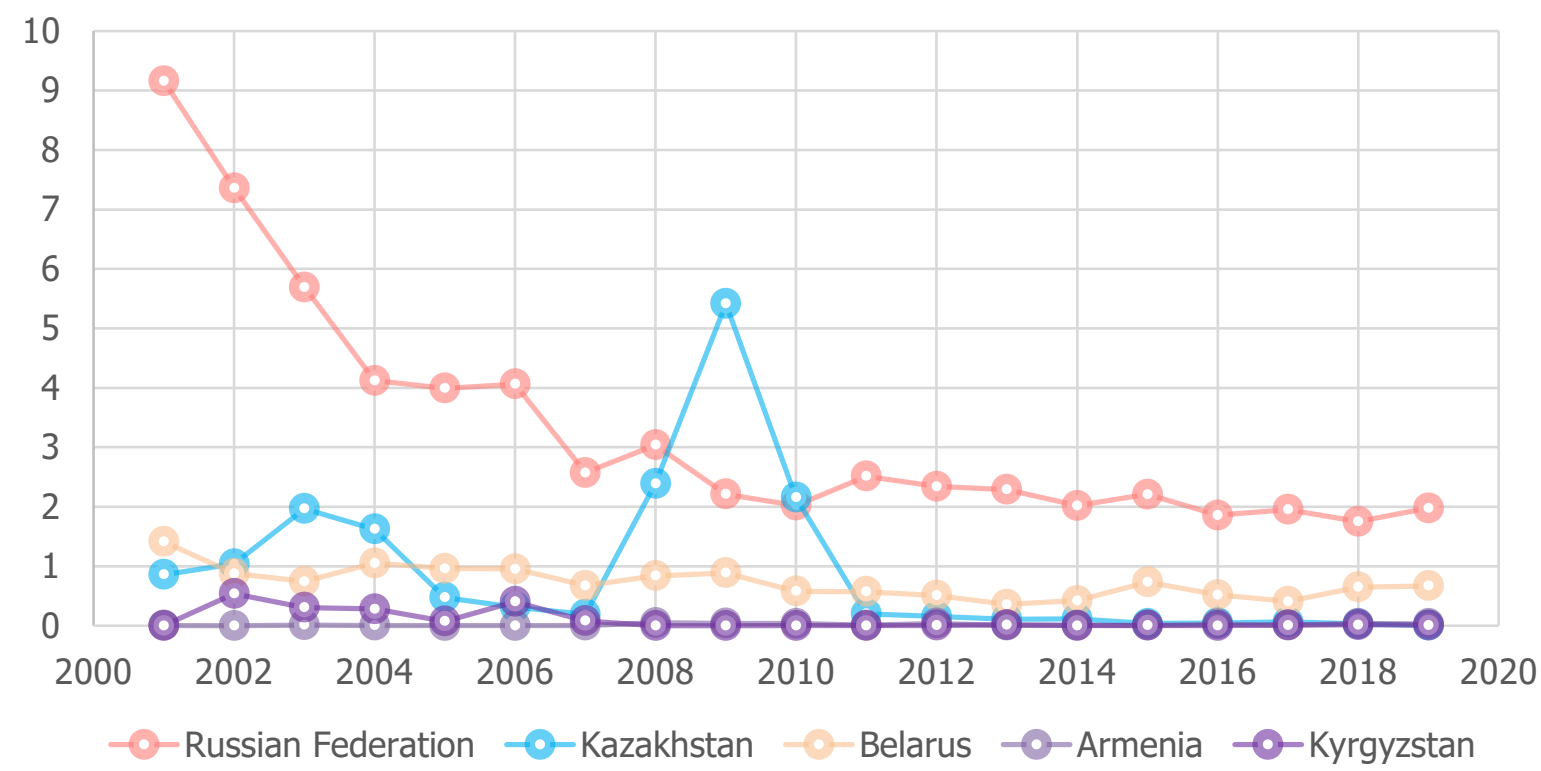

Source: author's own processing based on ITC data, 2021

Among the EAEU countries, Belarus can be classified as the second country with the highest trade intensity with the Slovak Republic. As the figure shows, in contrast to the Russian Federation, its development oscillated at approximately one level without extreme fluctuations in the range of $0.40-1.44$. The index reached values above 1 for only two years during the reviewed period, in 2001 and 2004. Meanwhile, in recent years, the intensity of trade by Belarus as an exporter was below 1 . The development of the intensity of Kazakh's trade with the Slovak Republic has been on a declining trend since 2011. This is largely due to the changing position of Kazakhstan in the world economy. Over the last nine years, Kazakhstan has more than doubled its exports compared to previous periods. The values of the intensity index varied in the range from 0.02 to 5.41. During the last two years, the intensity of trade was at the lowest level. The intensity of trade was very low in terms of exports from Armenia and Kyrgyzstan. Armenia ranged from 0 to 0.05 during the period and Kyrgyzstan from 0 to 0.53 . On this basis, it can be stated that their intensity is very low, which is understandable to the geographical distance and economic dimension of the countries.

\subsection{Trade intensity index of the Slovak republic with the EAEU}

The following figure offers us an insight into the development of the trade intensity index by Slovakia as an exporter. As in the case of imports, the Russian Federation is in the first place. During the entire period under review, the index was above level 1 . This allows us to state that the volume of Slovak exports to the Russian Federation is higher than would be expected from its position in the world economy. The highest value of the index 2.59, was reached in 2010 and the lowest 1.36 in 2019. The value of the index with Kazakhstan was above level 1 at the beginning of the period under review. Subsequently, however, it gradually decreased, except in 2010 and 2014, but even then the index did not exceed 1. In 2019, the intensity of trade of the Slovak Republic with Kazakhstan was 0.21 points. The intensity of trade with Belarus did not fall below 0.55 points throughout the period under review. It was above level 1 only once, in 2008. Surprisingly, the trade intensity index with Armenia also reached values above 1, that was in 2002 and 2004. Recent years display a gradual decline. In 2019, their 
trade intensity index was 0.15 points. Among the EAEU countries, Slovakia has the lowest trade intensity with Kyrgyzstan. The range of intensity index values ranged from 0.04 to 0.58 . In the case of Kyrgyzstan, we can see a growing trend over the last three years.

Fig. 3 Development of the trade intensity index by Slovakia to EAEU countries, 2001 - 2019

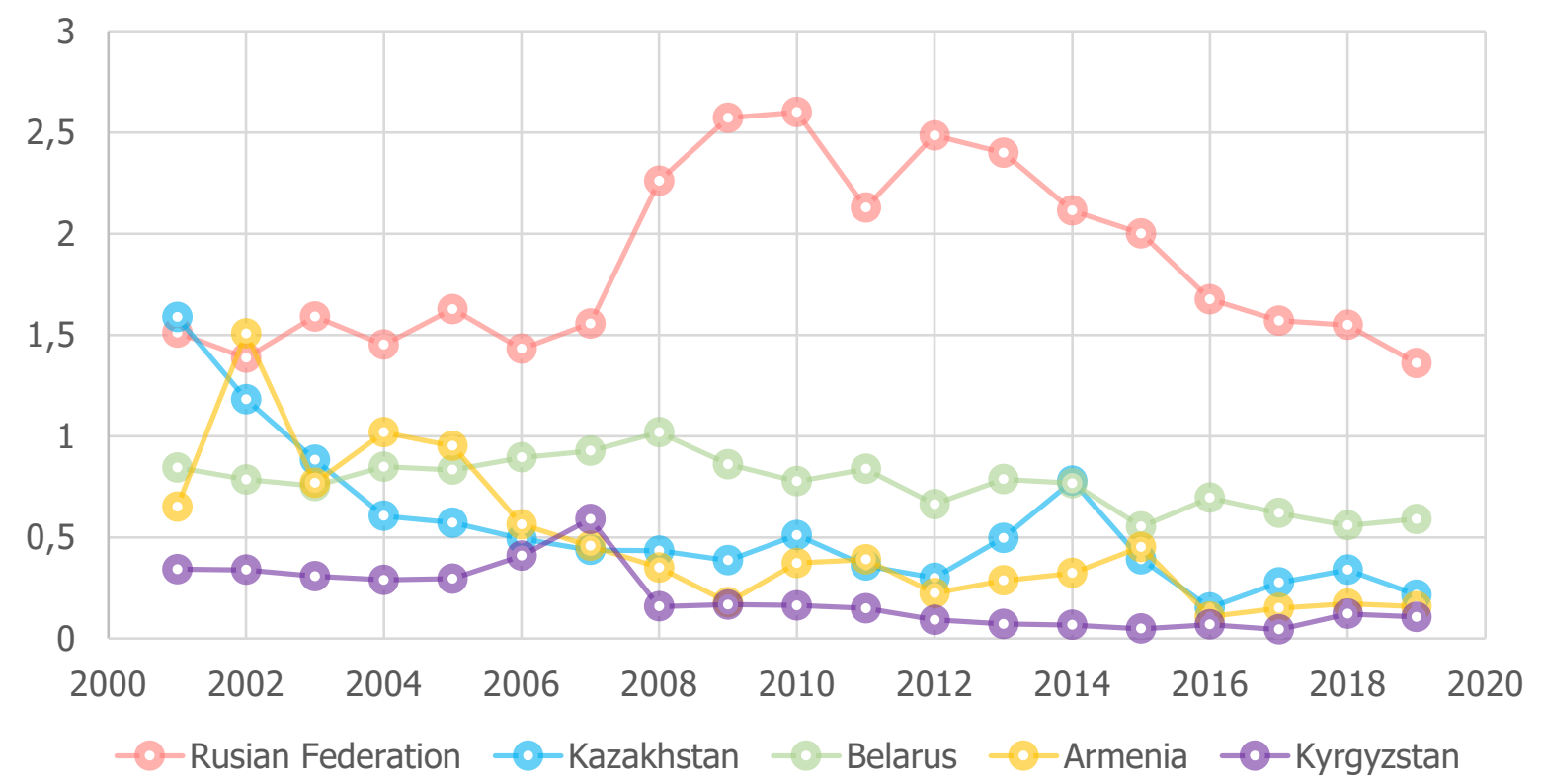

Source: author's own processing based on ITC data, 2021

Based on the analysis of trade intensity indices between the Slovak Republic and the EAEU countries, we can reach the following conclusions. In the case of Slovakia as an exporter and importer, we could observe that until 2009 (the first half of the period under review) the intensity developed more favorably than the next ten years. Among the EAEU countries, only the Russian Federation has been identified as a trading partner with a higher volume of trade than expected given its position in the world economy. During the last five years, the intensity of the Slovak Republic as an exporter to Belarus, Kazakhstan, Kyrgyzstan and Armenia was higher than their export positions. Simultaneously we must state a declining trend in the development of indices, although since 2016, there have been some signs of growth from both sides.

\subsection{Intra-industry trade between the Slovak Republic and selected the EAEU countries}

In this section, we assess the degree of trade cooperation within sectors between the Slovak Republic and selected countries of the EAEU. The results of the evaluation of the intra-industry index are in tables 1, 2 and 3. Table 1 presents the values of intra-industry trade between the Slovak Republic and the Russian Federation. In 2019, the highest value of the index was 0.79 in the SITC $2+4$ group (raw materials). In recent years, there has been a growing trend in this group, therefore the presence of intra-industry trade can be assessed. Based on a closer analysis at the HS2 level, it can be further defined that this is mainly intra-industry trade in groups HS 40 (rubber and articles thereof), HS 25 (ores, slag and ash), HS 72 (iron and steel). and HS 73 (articles of iron or steel). 
Tab. 1 Intra - industry trade between the Slovak Republic and the Russian Federation in the years 2008 - 2019

\begin{tabular}{|c|l|l|l|l|l|l|l|l|l|l|l|l|}
\hline SITC & $\mathbf{2 0 0 8}$ & $\mathbf{2 0 0 9}$ & $\mathbf{2 0 1 0}$ & $\mathbf{2 0 1 1}$ & $\mathbf{2 0 1 2}$ & $\mathbf{2 0 1 3}$ & $\mathbf{2 0 1 4}$ & $\mathbf{2 0 1 5}$ & $\mathbf{2 0 1 6}$ & $\mathbf{2 0 1 7}$ & $\mathbf{2 0 1 8}$ & $\mathbf{2 0 1 9}$ \\
\hline $0+1$ & 0.040 & 0.117 & 0.136 & 0.073 & 0.050 & 0.078 & 0.061 & 0.089 & 0.110 & 0.074 & 0.072 & 0.040 \\
\hline $2+4$ & 0.797 & 0.503 & 0.420 & 0.498 & 0.539 & 0.467 & 0.479 & 0.461 & 0.591 & 0.556 & 0.613 & 0.797 \\
\hline 3 & 0.000 & 0.000 & 0.000 & 0.000 & 0.000 & 0.003 & 0.000 & 0.000 & 0.004 & 0.000 & 0.000 & 0.000 \\
\hline 5 & 0.611 & 0.932 & 0.946 & 0.972 & 0.774 & 0.790 & 0.868 & 0.959 & 0.774 & 0.762 & 0.891 & 0.611 \\
\hline $6+8$ & 0.274 & 0.449 & 0.286 & 0.223 & 0.143 & 0.205 & 0.287 & 0.188 & 0.243 & 0.354 & 0.279 & 0.274 \\
\hline 7 & 0.086 & 0.086 & 0.129 & 0.131 & 0.121 & 0.132 & 0.095 & 0.192 & 0.124 & 0.173 & 0.139 & 0.086 \\
\hline 9 & $\mathrm{X}$ & $\mathrm{X}$ & 0 & $\mathrm{X}$ & $0 \mathrm{E}+00$ & $0 \mathrm{E}+00$ & $2 \mathrm{E}-05$ & $0 \mathrm{E}+00$ & $3 \mathrm{E}-05$ & $5 \mathrm{E}-05$ & $3 \mathrm{E}-05$ & $\mathrm{X}$ \\
\hline
\end{tabular}

Source: author's own processing based on Eurostat data, 2021

Note: $0+1-$ Food, drinks and tobacco, 2+4 - Raw materials, 3 - Mineral fuels, lubricants and related materials, 5 - Chemicals and related products, n.e.s., 7 - Machinery and transport equipment, 6+8 Other manufactured goods, 9 - Commodities and transactions not classified elsewhere in the SITC.

During the years 2009 to 2018, the high value of the index within the SITC 5 group (chemicals) was observed. Although it decreased significantly in 2019, given the proven trend, intraindustry trade can also be recognized within this group. At the HS2 level, it concerned the highest intra-industry trade in groups HS 30 (pharmaceutical products) and HS 28 (inorganic chemicals). Within the groups SITC $0+1$ (food, beverages and tobacco), SITC 3 (mineral fuels), SITC $6+8$ (industrial products) and SITC 7 (machinery and transport equipment), the value of the index was low, ergo we can classify the trade of these groups at the inter-industry level. In SITC 9 (other commodities and transactions not classified in any of the SITC groups), no trade in goods was recorded during some years, consequently, it was not possible to express the intra-industry trade index.

Tab. 2 Intra - industry trade between the Slovak Republic and Kazakhstan in the years $2008-2019$

\begin{tabular}{|c|l|l|l|l|l|l|l|l|l|l|l|l|}
\hline SITC & $\mathbf{2 0 0 8}$ & $\mathbf{2 0 0 9}$ & $\mathbf{2 0 1 0}$ & $\mathbf{2 0 1 1}$ & $\mathbf{2 0 1 2}$ & $\mathbf{2 0 1 3}$ & $\mathbf{2 0 1 4}$ & $\mathbf{2 0 1 5}$ & $\mathbf{2 0 1 6}$ & $\mathbf{2 0 1 7}$ & $\mathbf{2 0 1 8}$ & $\mathbf{2 0 1 9}$ \\
\hline $0+1$ & 0.000 & 0.000 & 0.000 & 0.000 & 0.033 & 0.000 & 0.096 & 0.259 & 0.556 & 0.860 & 0.113 & 0.202 \\
\hline $2+4$ & 0.000 & 0.022 & 0.000 & 0.000 & 0.000 & 0.000 & 0.000 & 0.035 & 0.127 & 0.214 & 0.001 & 0.086 \\
\hline 3 & 0.001 & 0.000 & 0.000 & 0.000 & 0.000 & 0.000 & 0.000 & 0.000 & 0.014 & 0.011 & 0.005 & 0.000 \\
\hline 5 & 0.507 & 0.001 & 0.000 & 0.000 & 0.000 & 0.000 & 0.000 & 0.000 & 0.370 & 0.375 & 0.979 & 0.786 \\
\hline $6+8$ & 0.748 & 0.257 & 0.908 & 0.867 & 0.000 & 0.001 & 0.014 & 0.000 & 0.056 & 0.104 & 0.000 & 0.117 \\
\hline 7 & 0.002 & 0.003 & 0.000 & 0.001 & 0.000 & 0.000 & 0.019 & 0.069 & 0.201 & 0.133 & 0.048 & 0.024 \\
\hline 9 & $\mathrm{X}$ & $\mathrm{X}$ & $\mathrm{X}$ & $\mathrm{X}$ & 0 & $\mathrm{X}$ & $\mathrm{X}$ & $\mathrm{X}$ & $\mathrm{X}$ & $\mathrm{X}$ & 0 & 0 \\
\hline
\end{tabular}

Source: author's own processing based on Eurostat data, 2021

Note: $0+1-$ Food, drinks and tobacco, 2+4 - Raw materials, 3 - Mineral fuels, lubricants and related materials, 5 -Chemicals and related products, n.e.s., 7 - Machinery and transport equipment, $6+8$ - Other manufactured goods, 9 - Commodities and transactions not classified elsewhere in the SITC.

We also monitor the development of the index of intra-industry trade between the Slovak Republic and Kazakhstan. Throughout the period under review, the index values are relatively low. Until 2012, intra-industry trade was recorded in the SITC $6+8$ group (other manufactured goods). In recent years trade between the Slovak Republic and Kazakhstan was limited 
to inter-industry trade. On the contrary, the presence of intra-industry trade in SITC 5 (chemicals) has appeared in the last two years. Within the other groups, the inter-industry exchange is observed. As in the previous case, it was not possible to express the index for SITC group 9 (other commodities and transactions not classified in any SITC groups) due to the absence of trade flows.

With Belarus, The Slovak Republic achieved a relatively high intra-industry trade within several groups (table 3). The highest values were recorded in SITC 5 (chemicals), although it decreased in 2019. The increase in intra-industry trade can be observed in SITC $2+4$ (raw materials) and SITC $6+8$ (other manufactured goods). Inter-industry trade is detected in SITC $0+1$ (food, beverages and tobacco), SITC 3 (mineral fuels) and SITC 7 (machinery and transport equipment). It was not possible to express the index in the SITC 9 (commodities and transactions not classified elsewhere in the SITC).

Tab. 3 Intra - industry trade between the Slovak Republic and Belarus in the years 2008 2019

\begin{tabular}{|c|l|l|l|l|l|l|l|l|l|l|l|l|}
\hline SITC & $\mathbf{2 0 0 8}$ & $\mathbf{2 0 0 9}$ & $\mathbf{2 0 1 0}$ & $\mathbf{2 0 1 1}$ & $\mathbf{2 0 1 2}$ & $\mathbf{2 0 1 3}$ & $\mathbf{2 0 1 4}$ & $\mathbf{2 0 1 5}$ & $\mathbf{2 0 1 6}$ & $\mathbf{2 0 1 7}$ & $\mathbf{2 0 1 8}$ & $\mathbf{2 0 1 9}$ \\
\hline $0+1$ & 0.107 & 0.026 & 0.059 & 0.010 & 0.067 & 0.028 & 0.008 & 0.009 & 0.022 & 0.009 & 0.038 & 0.040 \\
\hline $2+4$ & 0.818 & 0.756 & 0.831 & 0.697 & 0.888 & 0.977 & 0.978 & 0.886 & 0.773 & 0.924 & 0.883 & 0.699 \\
\hline 3 & 0.002 & 0.006 & 0.003 & 0.001 & 0.001 & 0.023 & 0.101 & 0.005 & 0.068 & 0.024 & 0.000 & 0.000 \\
\hline 5 & 0.740 & 0.225 & 0.403 & 0.340 & 0.368 & 0.372 & 0.497 & 0.799 & 0.834 & 0.954 & 0.989 & 0.737 \\
\hline $6+8$ & 0.801 & 0.744 & 0.795 & 0.598 & 0.689 & 0.768 & 0.673 & 0.582 & 0.641 & 0.673 & 0.638 & 0.713 \\
\hline 7 & 0.225 & 0.205 & 0.088 & 0.092 & 0.030 & 0.034 & 0.068 & 0.136 & 0.079 & 0.172 & 0.057 & 0.182 \\
\hline 9 & $\mathrm{x}$ & $\mathrm{X}$ & $\mathrm{x}$ & $\mathrm{X}$ & 0 & $\mathrm{x}$ & $\mathrm{x}$ & 0 & $\mathrm{X}$ & 0 & $\mathrm{x}$ & $\mathrm{X}$ \\
\hline
\end{tabular}

Source: author's own processing based on Eurostat data, 2021

Note: $0+1-$ Food, drinks and tobacco, 2+4 - Raw materials, 3 - Mineral fuels, lubricants and related materials, 5 -Chemicals and related products, n.e.s., 7 - Machinery and transport equipment, 6+8 Other manufactured goods, 9 - Commodities and transactions not classified elsewhere in the SITC.

The performed analysis of the intra-industry index between selected EAEU countries and the Slovak Republic provided a clearer picture of the nature of their foreign trade participation at the sectoral level. It pointed to certain peculiarities of trade relations between the Slovak Republic and selected countries. Slovakia's intra-industry trade with these countries differed from each other. In general, it can be concluded that it mainly concerned the sectors: SITC $6+8$ (other manufactured goods), SITC $2+4$ (raw materials) and SITC 5 (chemicals).

\section{CONCLUSION}

Based on the examination of the development of Slovakia's foreign trade with the countries of the integration core of the EAEU in terms of trade intensity and intra-industry trade, we can draw the following conclusions.

Until 2009, the trade intensity index developed more favorably than the following ten years. In terms of trade intensity, only the Russian Federation has been identified among the EAEU countries as a trading partner with a higher volume of trade than expected given their position in the world economy. During the last five years, the intensity of the Slovak Republic as an exporter to Belarus, Kazakhstan, was higher than their export positions. Afterward, we observed a declining trend in the development of indices, despite that there have been some signs of growth from both sides since 2016. 
The assessment of the level of trade based on Grubel-Lloyd's approach between the EAEU countries and the Slovak Republic pointed to the growing presence of intra-industry trade with Kazakhstan and the Russian Federation. In general, it can be concluded that it mainly concerned the sectors: SITC $6+8$ (other manufactured goods), SITC $2+4$ (raw materials) and SITC 5 (chemicals).

\section{ACKNOWLEDGEMENT}

This paper is a part of a research project of the Ministry of Education, Family and Sports of the Slovak Republic VEGA No. 1/0039/20 The Importance of the Eurasian Economic Union for Shaping of EU Trade Strategies (with Implications for Slovakia).

\section{REFERENCES}

Baccini L., Dür A., \& Elsig M. (2018). Intra-Industry Trade, Global Value Chains, and Preferential Tariff Liberalization. International Studies Quarterly, 62(2), 329340. https://doi.org/10.1093/isq/sqy006

Brown, A. J. (1949). Applied Economics: Aspects of World Economy in War and Peace. The Journal of Economic History, 9(1), 112-113. https://doi.org/ 10.1017/S0022050700090756

Brulhardt, M. (1994). Marginal intra-industry trade: Measurement and relevance for the pattern of industrial adjustment. Review of World Economics (Weltwirtschaftliches Archiv), 130(3), 600-613.

Calderón C., Chong A., \& Stein E. (2007). Trade intensity and business cycle synchronization: Are developing countries any different?. SSRN Electronic Journal, 71(1), 1-21. https://doi.org/10.1016/j.jinteco.2006.06.001

Crespo, N. \& Fontoura, M.P. (2004). Intra-industry trade by types: What can we learn from Portuguese data? Review of World Economics, 140(1), 52-79.

Eurostat (2021). International trade in goods. Aggregated data. Retrieved on 10 January 2021 from https://ec.europa.eu/eurostat/databrowser/view/ext_It_intertrd/default/table?lang=en

Greenaway D., Egger H., \& Egger, P. (2005). Trade Liberalisation with Multinational Firms: Effects on Welfare and Intra-Industry Trade. University of Nottingham Research Paper, 2005/06. http://dx.doi.org/10.2139/ssrn.764445

Hamilton, C., \& Kniest P. (1991) . Trade liberalisation, structural adjustment and intra-industry trade: A note, Review of World Economics (Weltwirtschaftliches Archiv),127(2), 356-367.

International Trade Centre (2020). Bilateral trade between Armenia and Slovakia Retrieved 10 December 2020 from https://www.trademap.org/Bilateral_TS.aspx?nvpm=1\%7c051\%7c\%7c703\%7c\%7cTOTAL\% 7c\%7c\%7c2\%7c1\%7c1\%7c1\%7c2\%7c1\%7c1\%7c1\%7c1\%7c1

International Trade Centre (2020). Bilateral trade between Belarus and Slovakia. Retrieved 11 December 2020 from https://www.trademap.org/Bilateral_TS.aspx?nvpm=1\%7c112\%7c\%7c703\%7c\%7cTOTAL\% 7c\%7c\%7c2\%7c1\%7c1\%7c1\%7c2\%7c1\%7c1\%7c1\%7c1\%7c1

International Trade Centre (2020). Bilateral trade between Kazakhstan and Slovakia. Retrieved 13 December 2020 from https://www.trademap.org/Bilateral_TS.aspx?nvpm=1\%7c398\%7c\%7c703\%7c\%7cTOTAL\% 7c\%7c\%7c2\%7c1\%7c1\%7c1\%7c2\%7c1\%7c1\%7c1\%7c1\%7c1 
International Trade Centre (2020). Bilateral trade between Kyrgyzstan and Slovakia. Retrieved $11 \quad$ December $2020 \quad$ from https://www.trademap.org/Bilateral_TS.aspx?nvpm=1\%7c417\%7c\%7c703\%7c\%7cTOTAL\% 7c\%7c\%7c2\%7c1\%7c1\%7c1\%7c2\%7c1\%7c1\%7c1\%7c1\%7c1

International Trade Centre (2021). Bilateral trade between Russian Federation and Slovakia. Retrieved $\quad 10 \quad$ December 2020 from https://www.trademap.org/Bilateral_TS.aspx?nvpm=1\%7c643\%7c\%7c703\%7c\%7cTOTAL\% 7c\%7c\%7c2\%7c1\%7c1\%7c1\%7c2\%7c1\%7c1\%7c1\%7c1\%7c1

Kim, I. (2017). Political Cleavages within Industry: Firm-level Lobbying for Trade Liberalization. American Political Science Review, 111(1), 1-20. https://doi.org/10.1017/S0003055416000654 Kojima, K. (1964). The pattern of international trade among advanced countries. Hitotsubashi Journal of Economics, 5(1), 16-36 https://doi.org/10.150578091

Lipson, C. (1982). The transformation of trade: The sources and effects of regime change. International

https://doi.org/10.1017/S0020818300019007

Organization, 36(2),417-455.

Manger, M. (2012). Vertical Trade Specialization and the Formation of North-South PTAs. World Politics, 64(4), 622-658. https://doi.org/10.1017/S0043887112000172

Milner H. V. (1997). Industries, Governments, and Regional Trade Blocs. In The Political Economy of Regionalism, pp.77- 106. New York: Columbia University Press.

Thom R., Mcdowell, M. (1993). Measuring marginal intra-industry trade, Review of World Economics (Weltwirtschaftliches Archiv), 135(1), 48-61.

World Bank. (2010). Trade Indicators. Retrieved on 12 January 2021, from https://wits.worldbank.org/wits/wits/witshelp/Content/Utilities/e1.trade_indicators.htm

World Bank (2013). Trade Outcome Indicators. Retrieved on 14 January 2021 from http://wits.worldbank.org/WITS/docs/TradeOutcomes-UserManual.pdf 